\title{
-Mini Review- Advances in ecological studies of tropical secondary forests
}

\author{
Li XUE ${ }^{1, *}$, Ling-hai ZENG ${ }^{2}$, Hong-feng $\mathrm{WANG}^{2}$ and Yuan-zhao $\mathrm{HoU}^{3}$ \\ College of Forestry, South China Agricultural Univiversity, Guangzhou, 510642, P. R. China \\ ${ }^{2}$ Academy of Guangdong Forestry, Guangzhou 510520, P.R. China \\ ${ }^{3}$ Chinese Academy of Forestry, Beijing 100091, P.R. China \\ * Corresponding author: Li XUE, E-mail: forxue@scau.edu.cn, Tel:+86-20-85283259, Fax:+86-20-85280259
}

\begin{abstract}
Tropical secondary forests own enormous potential and ecological function due to their vast area, and are an increasingly important component of the forest resources in the tropics. This paper reviews main research outcomes of secondary forests during their succession process. Soil-stored seeds significantly contribute to the development of secondary forests, increased levels of incident light temperature stimulate seed germination, whereas remnant vegetation and seed predator have strongly negative influence on the rate of initial colonization. Species and number of secondary forests generally increase with succession process. Early successional species are generally shade-intolerant while late successional species are shade-tolerant. The time frame that plant species richness in secondary forests approach old-growth forests varies considerably depending on forest type, type and intensity of past land use, and environmental conditions. Plantation can accelerate germination and growth of seeds by improving the light, temperature and the degree of humidity of soil surface layer, so that they greatly accelerate the processes of plant succession. Most herbivores feed in secondary forests because pioneer species in secondary forests do have little or no mechanical or chemical protection against herbivores and many early and late serial tree species in secondary forests produce edible fruits in large quantities. Environment and fire have some effects on secondary forest succession. In early succession, relatively more biomass is allocated to resource acquiring tissues (leaves and fine roots) and in later stages more is allocated towards structural materials (woody stems and coarse roots). The nutrient cycling of secondary forests is quick during approximately the first 15
\end{abstract}

years of succession and it decreases as forests age. The losses of soil organic matter and $\mathrm{N}$ due to deforestation and burning decreases soil fertility of secondary forests.

Key words: composition, construction, nutrient cycling, succession, tropical secondary forests

\section{INTRODUCTION}

In the world's tropical region, many tropical forests were changed into secondary forests or degraded to wasteland, because of ruining wood for crop and timber derived increasing population. According to the ITTO data, tropical secondary forest or degraded wasteland accounts for $60 \%$ of tropical forest areas (ITTO, 2002). Tropical secondary forest owns enormous potential because of its strong plasticity and vast area. Meanwhile, the tropical secondary forest can improve environment, prevent pollution, fix $\mathrm{CO}_{2}$ (Fearnside and Guimaraes, 1996), provide the forest instauration modes (Lugo, 1992), provide the sanctuary for biological diversity and has various outputs at the same time (Chazdon and Coe, 1999). In the tropics, people's exploitation to the tropical secondary forests is more than primary forests. The great majority of collecting fuel wood, pasturing, vacillant agriculture, collecting non-wood forest products, and production exercises which are closely-related with the life of local people living in forest regions and nearby the regions are conducted in secondary forests (FAO, 1996; Dotzauer, 1998). They are also important with environmental services, such as protecting soils from erosion processes, fixing and storing carbon, conserving biodiversity in fragmented landscapes (most of them are presented in summary fashion in Table 1). With the progress of city and industrialization, the area of tropical secondary forests will increase this century (Thomlinson 
Table 1. Characteristics of secondary forests (compiled from ITTO, 2002).

\begin{tabular}{|c|c|}
\hline Location & Accessible area \\
\hline Intensity of disturbance & Severe intensity, caused by the clearing of at least $90 \%$ of the original forest cover \\
\hline \multirow[t]{2}{*}{ Common causes of disturbance } & Clear-cutting, burning and abandonment of area \\
\hline & Catastrophic large-scale natural disturbances: fire, flooding, storms, landslides. \\
\hline Regeneration & Seed dispersion and germination from tree stump and root stake \\
\hline Vegetation development process & $\begin{array}{l}\text { A sequence of successional changes takes place after the perturbation. In this } \\
\text { process several phases or stages with specific floristic, structural and dynamic } \\
\text { characteristics can be distinguished. Plant species composition changes in } \\
\text { dominance gradually from early to late successional species }\end{array}$ \\
\hline Species composition & Relatively uniform species composition \\
\hline Tree growth & Rapid \\
\hline Biomass accumulation & Rapid at early stages of succession and slow at later stages of succession \\
\hline Productivity & $\begin{array}{l}\text { Varies with site conditions, time since settlement, the number of crop-fallow cycles } \\
\text { at a particular site, the type and intensity of land use during the cropping stage, } \\
\text { and the prevalence of disturbances }\end{array}$ \\
\hline Nutrient cycling & Rapid at early stages of succession and slow at later stages of succession \\
\hline Soil fertility & Low \\
\hline Total biodiversity & Low to medium sometimes high \\
\hline Environmental services & $\begin{array}{l}\text { Good. If properly restored and managed, they protect soils from erosion } \\
\text { processes; regulate the water regime, favouring the hydrological cycle and } \\
\text { reducing water loss thru run-off on hillsides; fix and store carbon, and help } \\
\text { conserve genetic resources. }\end{array}$ \\
\hline Resource property & Variety of supply of timber and non-wood forest products \\
\hline Future availability of land & Increasing \\
\hline Future source of timber production & Increasing \\
\hline
\end{tabular}

et al. 1996). Therefore, enhancing research of secondary forests has important meaning for promoting their management and economic value.

There were many researches on plant community, succession process and niche of tropical secondary forests from an ecological viewpoint. The study of tropical secondary forests began from the 1950's. The earliest study of secondary forests is Greig-Smith's ecological investigation on stand structure of three secondary forests in Reggae Islands Trinidad in 1952. Afterward, Bartholomew et al. (1953) reported biomass and nutrient contents of 2 to 18 year secondary forests developed from humid tropical forests after being slash-and fire in the Congo; Ross (1954) studied stand structure of 5 to17 year secondary forests developed from dry tropical forests being slashed-and-burned 23 years ago in Nigeria; The study range of secondary forests became more and more wide and many papers were published in the last 20 years. For example, Guang (1996) studied biomass, primary production, litterfall and nutrient of monsoon evergreen broadleaved forests growing buried wasteland in Hong Kong and Guangdong, China; Zimmerman et al. (1996) summarized the influence of land use on secondary forests developed from tropical lowland rain forests being farmed, herded or selective felled in Puerto Rico.

The objective of this review is to summarize main research outcomes in structure and function of secondary forests.

\section{DEFINITION AND TYPES OF SECONDARY FORESTS}

Secondary forests were defined as "Forest regenerating largely through natural processes after significant human disturbance of the original forest vegetation at a single point in time or over an extended period, and displaying a major change in forest structure and/or canopy species composition (Chokkalingam et al., 2001). There are five main types of secondary forests (Table 2).

The above types of secondary forests can be basically divided into secondary forests which come from rest area_-swidden fallow secondary forests and secondary forest gardens and secondary forests which come from non-rest area_post-extraction secondary 
Table 2. Types of secondary forestry (from Chokkalingam et al., 2001 and ITTO, 2002).

\begin{tabular}{|c|c|c|}
\hline Types & Definition & Examples \\
\hline $\begin{array}{l}\text { Post-extraction } \\
\text { secondary forests }\end{array}$ & $\begin{array}{l}\text { Forests regenerating after significant reduction } \\
\text { in the original forest vegetation through tree } \\
\text { extraction at a single point in time or over an } \\
\text { extended period, namely forest - harvest- } \\
\text { regeneration. }\end{array}$ & $\begin{array}{l}\text { Dipterocarp-dominated forests transformed } \\
\text { into forests dominated by short-lived Trema } \\
\text { orientalis and Macaranga spp., Alphitonia sp., } \\
\text { and Mallotus spp. following intensive logging in } \\
\text { the Philippines }\end{array}$ \\
\hline $\begin{array}{l}\text { Swidden fallow } \\
\text { secondary forests }\end{array}$ & $\begin{array}{l}\text { Forests regenerating in woody fallows of } \\
\text { swidden agriculture for the purpose of restoring } \\
\text { the land, for cultivation again, namely forest- } \\
\text { clear —-burn-crop-fallow-clear. }\end{array}$ & $\begin{array}{l}\text { Lower montane rain forests transformed into } \\
\text { forests dominated by Schima wallichii, Eurya } \\
\text { acuminata, Castanopsis armata, etc. in shifting } \\
\text { cultivation fallows of northern Thailand }\end{array}$ \\
\hline $\begin{array}{l}\text { Secondary forest } \\
\text { gardens }\end{array}$ & $\begin{array}{l}\text { Considerably enriched swidden fallows, or less } \\
\text { intensively managed smallholder plantations } \\
\text { where substantial spontaneous regeneration } \\
\text { is tolerated, maintained, or even encouraged, } \\
\text { namely forest-clear-burn-crop- } \\
\text { considerably enriched fallow. }\end{array}$ & $\begin{array}{l}\text { Dipterocarp-dominated forests converted to } \\
\text { jungle rubber systems after swidden cultivation } \\
\text { in Kalimantan }\end{array}$ \\
\hline $\begin{array}{l}\text { Post-fire } \\
\text { secondary forests }\end{array}$ & $\begin{array}{l}\text { Forests regenerating after significant reduction } \\
\text { in the original forest vegetation due to a human- } \\
\text { induced fire or succession of fires, namely } \\
\text { forest-fire-regeneration. }\end{array}$ & $\begin{array}{l}\text { white spruce (Picea glauca) stands transformed } \\
\text { into aspen (Populus tremuloides) and paper } \\
\text { birth (Betula papyrifera) following fire in boreal } \\
\text { forests of Alaska }\end{array}$ \\
\hline $\begin{array}{l}\text { Rehabilitated } \\
\text { secondary forests }\end{array}$ & $\begin{array}{l}\text { Forests regenerating on degraded land, often } \\
\text { aided by rehabilitation efforts, or the facilitation } \\
\text { of natural regeneration through measures such } \\
\text { as protection from chronic disturbance, site } \\
\text { stabilization, water management and planting, } \\
\text { namely forest-degraded land-rehabilitation + } \\
\text { natural regeneration. }\end{array}$ & $\begin{array}{l}\text { Native plant species recruitment in North } \\
\text { Queensland following rehabilitation efforts on } \\
\text { degraded forest lands. Most common species } \\
\text { regenerating were Omalanthus novo-guineensis } \\
\text { and Cryptocarya triplinervis }\end{array}$ \\
\hline
\end{tabular}

forests, post-fire secondary forests and rehabilitated secondary forests. The environmental benefits of fallow include restoration of soil stability and fertility and the enhancement of useful biodiversity. Post-extraction secondary forests cause forest ecosystem slow decline through selective logging. On the conditions of intensive forest exploitation for post-extraction secondary forests and post-fire secondary forests, ecosystems rapidly decline, resulting in large tracts of degraded secondary forests. In rehabilitated secondary forests, seed sources are often absent and the ground vegetation dense and highly competitive, and silvicultural interventions can facilitate the survival and growth of existing seedlings and accelerate forest rehabilitation.

\section{SEEDS OF TROPICAL SECONDARY FORESTS}

Development of secondary forests starts from seed dispersion and from root stake. Seed dispersion contributes to the development of secondary forests, but soil-stored seeds to forest regrowth is more important (Garwood, 1989), which contributes much more than that of recently dispersed seeds for most species (Young, 1987). The potential of secondary forests to regenerate from soil-stored seeds diminishes with increasing intensity of land use. Aide and Caveliev (1994) suggested that in severely degraded grasslands in the Sierra Nevada de Santa Marta, Colombia, the effect of forest regeneration from a seed bank is less important than the intensity of land use. Usually, the species richness and abundance of vegetation that developed from the clearing of old-growth forest tends to be poorer than those arising from cleared sites previously supporting successional vegetation (Young, 1987). The dominant type of land use in the surroundings influences floristic composition and density. For example, secondary forests close to agricultural or otherwise deforested land contain large amounts of light-demanding shrub and herbaceous species, whereas the soil seed banks of secondary forests have a smaller proportion of herbage (Dupuy and Chazdon, 1998). Increased levels of incident light temperature stimulate seed germination (Raich and Gong, 1990). Birds and other animals contribute to forest regeneration as seed dispersers (Oberhauser, 1997).

Remnant vegetation can strongly influence seed 
dispersal. In extensively deforested area, spatial distance may be a critical barrier to succession. Aide and Cavelier (1994) found no dispersed seeds in pastures at only 20 $\mathrm{m}$ away from the nearest forested patch. Parrotta (1993) has observed a significant negative correlation between seedling density distance and nearest possible seed source. After seeds are dispersed, seed predation is another important obstacle to tree establishment. Seed removal was higher in abandoned slash-and-burn farms than in adjacent forest in the upper Rio Negro, Venezuela (Uhl, 1987). In Paragominas, Brazil, more than $80 \%$ seed removal within 20 days for six out of 11 tree species examined, and the probability of small seeded species arrival into pastures was higher than those of larger seeded species, but the probability of seed predation was lower for the latter (Nepstad et al. 1996). Xiao et al. (2004) found that the big nuts were better survived with longer cache lifetime, longer dispersal distances and higher proportion of emerged seedlings than small nuts. In contrast, Holl and Lulow (1997) observed no obvious correlation between seed size and seed removal rates in an abandoned pasture of Costa Rica.

\section{THE COMPOSITION AND CONSTRUCTION OF TROPICAL SECONDARY FORESTS}

Forest succession is characterized by changes of species composition and community structure. Plant species and number of secondary forests generally increase with succession process. Kellman (1970) discovered the plant species number of secondary forests was almost the same as that of nearby mature forests. Some researches found younger secondary forests have more tree species than old ones. For example, Laska (1997) pointed out in analyzing 12-year and 25-year secondary forests in Costa Rica, the younger forest growth is richer and has more plants per plot than a 25-year old forest. In general, old growth forest tree assemblages are more diverse than secondary growth tree assemblages in the tropics. Younger secondary growth forest has a more open canopy structure than older growth forests, allowing higher levels of light at shrub layer which may result in shrub assemblages of higher diversity than adjacent old growth forest. Although the basal area, tree height and biomass of the old secondary forest approached that of the primary forest, mortality, recruitment, turnover and tree growth rates were greater in the old secondary forest. The seed bank of the old secondary forest contained more than double the number of seeds of the primary forest seed bank and many more seeds were of shrub species (Brearley et al. 2004).

Early successional species are generally shadeintolerant while climax or late successional species are shade-tolerant, being found under their own canopy or that of early successional species. Cain and Shelton (2001) found that early successsional tree species were shadeintolerant pine during secondary succession in Arkansas, USA. With succession progressive, the shade-intolerant pines declined and the more shade tolerant hardwoods increased, the canopy gradually becomes multi-layered with the intolerant pines occupying the upper-most layer followed by the oaks and other intermediatetolerant canopy species, and then the most shade-tolerant members of the community develop to midcanopy, and finally they attain dominant canopy positions due to pine individual mortality from senescence or collective mortality form catastrophic disturbance. In the lowland moist and wet Neotropics, the first decade of forest succession after site abandonment is dominated by grasses, shrubs, and forbs, which are eventually shaded out by short-lived, light-demanding "pioneer" tree species. After this period, the canopy is dominated by long-lived, taller-statured, and light demanding tree species, and sometimes much larger-sized and even longer-lived species. Eventually, the canopies of these secondary stands may be replaced by other shade tolerant species characteristic of old-growth forest (Guariguata et al., 1997, Denslow and Guzman, 2000).

In India, when a forest is converted to farmland, perturbations due to fire, the introduction of crop species, weeding and other disturbances during crop harvest all result in a large reduction in the number of species. During secondary succession, the number of species increases gradually (Toky and Ramakrishnan, 1983). The change in community structure was very marked at the low altitude, from the initial weedy herbs, to a bamboo forest and, finally, to a mixed broad-leaved forest (Ramakrishnan and Kushwaha, 2001).

Species composition of secondary forests is closed to that of primary forests after secondary succession for few centuries. For example, Saldarriga et al. (1988) observed a small seedling with species characteristic of a primary forest become the dominant species for no longer than 60 years. With succession process, forest basal areas tended to increase and total individual density decreased, individual with $\mathrm{DBH}>10 \mathrm{~cm}$ increased (Lugo, 1992).

Young stands characterize higher tree densities, lower basal areas, and shorter canopy heights compared to old growth forest (Aide et al., 1996; Denslow and 
Guzman, 2000). Tree species characteristics change with succession stages. Compared with late successional tree species, early successional tree species attain a narrow crown form with rapid extension growth from the main axis, a faster rate of branch production of different orders, which ensure them faster growth, capitalizing upon the high light availability in a transient environment; the early successional species have a higher rate of leaf production, faster turnover rate, and consequently a larger proportion of younger leaves to older ones. Root architecture and the consequent ability to exploit different profiles of the soil for early successional species is different to that of late successional species. With the rapid accumulation of nutrients in the surface layers of the soil after the clear cutting of a forest, the early successional species tend to distributes their roots in more surface soil, so as to absorb nutrients, whereas roots of the late successional trees have more uniform distribution down the profile (Ramakrishnan and Kushwaha, 2001).

\section{PLANT SPECIES OF TROPICAL SECONDARY FORESTS AND LAND USE INTENSITY}

Though plant species richness in secondary forests can approach old-growth values within a few decades after site abandonment, returning to a species composition similar to old-growth forest will be a much longer process (Finegan, 1996). Abandonment time and land use history are of overwhelming importance in determining the species composition of recovering forests (Chinea et al. 2003). This time frame will vary considerably depending on the intensity of past land use. Under light-to-moderate land use intensity, and when seed sources are nearby, plant species richness rapidly increases, which reaches similar values comparable to old-growth forest after a few decades. However, as intensity of past land use increases, recovery of species richness become slow due to soil compaction, propagule dispersal limitation, and fire occurrence (Nepstad et al. 1996). In montane forests, recovery of canopy composition with respect to old-growth forest may be reached much more rapidly than at low elevations (Olander et al. 1998). Past land use intensity also affects the composition of early colonizers. In wet Costa Rica, e.g., when land abandonment immediately follows forest cutting there tends to be a notable reduction in abundance of typical short-lived species. The absence of exposed mineral soil, and the presence of residual vegetation and litter may make it difficult for very small-seeded, short-lived pioneers to germinate and establish (e.g. Putz, 1983). In Puerto Rico, Cecropia could not colonize abandoned pastures the first decades post-abandonment (Aide et al. 1996), in spite of being the most common tree invader after landslides. The type of past land use may also affect species composition following abandonment. Zimmerman (1995) found that in 60-year-old abandoned coffee vs. abandoned pasture sites, tree and shrub species diversity was similar but floristic composition was greatly different. Rivera and Aide (1998) reported that similar species richness were found in secondary forests on abandoned pasture sites and on abandoned coffee sites, but their species composition was different. Degradation affects both the productivity and the species richness of secondary vegetation that may subsequently develop on the land. On abandoned subsistence farms in the Venezuelan Amazonand pastures in northeastern Brazil, the mean number of tree species in 0.01 ha plots was three to six times greater on cleared and burned but immediately abandoned land than on land grazed or cultivated in varying degree (Uhl, 1987; Uhl et al. 1988).

\section{EFFECT OF ARTIFICIAL STANDS ON TROPICAL SECONDARY FORESTS}

Plantation can accelerate germination and growth of seed by improving the light, temperature and the degree of humidity of soil surface layer (Parrotta et al. 1997). Plantation monocultures established on degraded tropical sites can greatly accelerate processes of plant succession and rates of biomass and nutrient accretion in vegetation and soils. In comparison with adjacent control areas, 4.5-year-old Albizia lebbek plantation stands showed a 11-fold increase in aboveground plant biomass, a 7-fold increase in root and forest floor biomass, and marked differences in aboveground and belowground structure (Parrotta et al. 1997). Otsamo (2000) found that In Riam Kiwa region, Indonesia, planting artificial plantations with suitable foreign species, such as Gmelina arborea, Paraserianthes falcatariamay accelerated natural regeneration of local tree species. Plantation species had a considerable influence over understorey seedling/sapling density and species richness, which was highest in the $A$. mangium stands with an average of 3,042 seedlings of 29 species per hectare. Therefore, only successful plantations with good growth and early canopy closure can act as initial steps in the secondary succession of Imperata grasslands. Otherwise the stands will remain uneven, the amount of Imperata grass will be 
very high and secondary succession will be as slow as it is in grassland areas.

Lugo (1992) compared the structure and dynamic of secondary forests with those of paired Pinus caribaea and Swietenia macrophylla plantations of similar age. Although the small-unmanaged plantations had a lower number of species in the understory than paired secondary forests, the understory of the older plantations developed high species richness, including many of native tree species. After 17 years, native tree species invaded the overstory of plantations. After 50 years the species richness in the understory of a $S$. macrophylla plantation approached that of its paired secondary forest.

Oberhauser (1997) studied four Pinus kesiya plantations, aged 7, 12, 21 and 28 years, growing on abandoned agricultural areas. Results of the study revealed a high number of vascular species in the plots. Increasingly complex forest structure could be observed as mid-and low-level canopies had developed and other species replaced pines in the overstorey. Increasing numbers of animal dispersed tree species became established in the older plantations. Recovery of woody vegetation was faster in plantations than in areas not afforested with $P$. kesixa. It appears that $P$. kesiva plantations can enhance establishment of mixed forests.

\section{TROPICAL SECONDARY FORESTS AND ANIMALS}

Conversion of primary forests to secondary forests has a negative impact on the populations of arboreal mammals, because it alters their habitat and decreases food supply (Kartawinata et al. 2001). Some secondary forests near high forests may help in maintaining high wildlife diversity because high forests provide most of the required habitats for wildlife, but secondary forests contain more foods for animals. Pioneer species that are common in secondary forests do have little or no mechanical or chemical protection against herbivores and this may be one reason that most herbivores feed in secondary forests. Also, many early and late seral tree species in secondary forests produce edible fruits in large quantities. These are reasons why most herbivores like to find foods in secondary forests (Perera, 2001). The situation for browsing animals may be improved by the luxuriant secondary forest regeneration. Some species of birds require a large area of relatively undisturbed forest to maintain breeding populations or mature trees for nesting, whereas colonizing birds prefer to feed in disturbed forest and their numbers increase in secondary forests (Kartawinata et al. 2001). Natural secondary forests were a better habitat for forest birds than the plantation. Compared to the plantation, there were most tree species in secondary forests, and both bird density and the number of breeding species were much high. Many studies have shown that plantations are unsuitable habitats for some animal species, because of a lack of food and complexity of stand structure and species composition (e.g. Gjerde and Sætersdal, 1997; Díaz et al. 1998; Garcia et al. 1998). Some researchers found that bird species diversity is correlated with the vegetation complexity in a habitat (Kwok and Corlett, 2000).

\section{TROPICAL SECONDARY FOREST SUCCESSION AND ENVIRONMENT}

Environment has important effect on secondary forest succession. Leak (1991) reported that successional attributes of secondary forests in New Hampshire, USA: Successional direction varies by site. Fine till soils tend toward beech, sugar maple, and associated hardwoods; sandy tills toward a predominance of beech; shallow or dry sites toward hemlock and spruce. In Amazônia, moisture limitations are likely factor to constrain secondary forest growth (Johnson et al. 2000), particularly where there is a pronounced dry-season (Nepstad et al. 1994).

Rivera and Aide (1998) found in studying the karst region of Puerto Rico that species diversity of trees greater than $1 \mathrm{~cm}$ DBH was high in abandoned pastures in comparison with abandoned coffee plantations. The higher diversity in the abandoned pasture sites may be due to the presence of both light demanding and shade tolerant species that co-occur at this stage of forest development. The unique topography of the karst region may be most important factor contributing to the rapid recovery of secondary forest. Karst topography includes long narrow valleys surrounded by hill with steep slopes. This topography protects the valleys from strong winds during hurricanes and tropical storms. In addition, the accumulation of soil and organic matter in the valley bottoms creates better conditions for plant growth. The long narrow valleys will be more protected from direct sun light and less soil erosion.

Aboveground microhabitat differences influence early plant composition during secondary succession (Uhl et al. 1981), and small-scale variation in soil nutrients has the potential to affect the distribution, composition, and growth of colonizing species. Harcombe (1977) found in examining successional trajectories that herbs 
dominated fertilized plots, while shrubs and trees dominated unfertilized plots during the same time period. Floristic and life-form composition during secondary forest succession are influenced by the availability of soil resources. Species with high growth rates may be disproportionately favored under ample resource levels which leads to their over dominance during early succession because slow-growing species tend to be less responsive to enhanced resource levels (Chapin et al. 1986). Soil resources do not only influence species composition of a site, it also can affect the availability of these resources to other species and thus further affect successional trajectories. Local variation in soil fertility can affect not only structure, but also the distribution of tree species. Herrera and Finegan (1997) reported that spatial distributions of Vochysia ferruginea concentrated on steeper slopes with acid soils, while Cordia alliodopra were more abundant on gentler topography with more basic soils. Moreover, these within-stand differences in canopy dominants were found to significantly influence understory floristic composition and species richness.

Altitude has certain effect on species composition. At lower altitudes, the dominant species in old-growth stands with a strong sprouting capacity also dominated secondary stands, and species composition of secondary and old-growth stands was similar, whereas at higher altitudes, the dominant species in old-growth stands had little sprouting capacity and were poorly represented in diverse secondary stands, and secondary stands had greater species diversity than old-growth stands (Aiba et al. 2001).

Logging and canopy gap have important effect on the regeneration of second forests. 8 years after selective logging, density and species richness in secondary stands were found lowered as compared to pre-harvest levels, but no major changes in family level taxonomic composition were observed (Cannon et al. 1998). Light levels under canopy and in gaps are highly heterogeneous. Large gaps have a hot, dry microclimate that increases mortality; excess shade will reduce growth (ITTO, 1989). Clearance of undergrowth to at least $10 \mathrm{~m}$ around planted patches would result in greater growth rates in planted seedlings and accelerate the regeneration of forest (Bebber et al. 2002).

Hurricanes contribute to regional landscape-scale variation in both stand structure and species composition. Hurricanes cause moderate to severe defoliation and can directly damage and kill trees through uprooting, breakage and loss of minor and major branches, and stem breakage (Walker, 1991). Hurricane winds directly affected large individuals by uprooting and bole snapping, and indirectly affected understory individuals by falling canopy trees and debris (e.g. Basnet et al. 1992; Fu et al. 1996). The death of individual stems reduced competition and increased light and nutrient availability, resulting in increasing growth of surviving stems into larger size classes (Pascarella et al. 2004).

Echeverría and Lara (2004) found in studying environmental influence in secondary forests in southern Chile that higher diameter-growth rates were associated with intermediate annual rainfall, a short dry period, and sandy soil. Lower rates were associated with an intermediate frost-free period, a low summer humidity index, a long dry period and silty soil.

\section{BIOMASS AND PRODUCTIVITY OF TROPICAL SECONDARY FORESTS}

Above-ground biomass, forest stand volume, and basal area increase slowly at the initial stages, then they rapidly increase in advanced stages. In contrast, average stand diameter and height increase relatively fast in initial stages, and then increase slowly in advanced stages ( $\mathrm{Lu}$ et al. 2003).

Typically, secondary forest succession is characterized by shifts in the biomass allocation of the plant community. In early succession, relatively more biomass is allocated to resource acquiring tissues (leaves and fine roots) and in later stages more is allocated towards structural materials (woody stems and coarse roots). Fine root ( $<2 \mathrm{~mm}$ diameter) biomass accumulates at a slower rate than leaf biomass, but its recovery can still be quite rapid. Secondary forests can also have similar or higher fine root biomass than old-growth forest after 1 to 10 year post-abandonment (Cavelier et al. 1996). Secondary forests are generally sinks of biomass as they re-vegetate, and thus they are also sinks of atmospheric carbon (Lugo and Brown, 1992). In general, secondary forests rapidly accumulate up to 100t/ha of biomass for about 15-20 years after abandonment (Brown and Lugo, 1990). Aboveground biomass usually shows an asymptotic pattern with time, although factors such as climate and past land use tend to affect the rate of accumulation.

Tropical secondary forests develop maximum biomass of 100 ton/ha in their first 15 years. After 15 years, forests diverge in the amount of biomass accumulation. Few of the forests accumulated more than $200 \mathrm{t} / \mathrm{ha}$ by age 80 years. Most tropical secondary forests reach leaf biomass peak by age 20 years and then remain steady or decrease slightly, their root biomass 
increases slowly with age, whereas their wood biomass increases rapidly during the first 15 to 20 years, followed by a steady but slower rate until maturity (Brown and Lugo 1990; Lugo 1992). Ticktin and Nantel (2004) compared the population dynamics of the understory under old-growth and secondary rainforests in Southeast Mexico. The results show that growth rates of secondary forest populations are higher than those of old-growth populations under both ramet-harvest and no-harvest conditions. Secondary forests that originated after shifting cultivation grow faster than secondary forests developing in abandoned pastures (Fearnside and Guimaraes, 1996).

\section{NUTRIENT CYCLING IN TROPICAL SECONDARY FORESTS}

Plants absorb nutrients for tissues grow and return some of the nutrients by litterfall to the soil. The vegetation of secondary forests quickly accumulates nutrients into leaves and roots during approximately the first 15 years of succession (Brown and Lugo, 1990). Such rapid nutrient accumulation is accompanied by nutrient return to soil (Lugo, 1992). With forest growth, however, most of the biomass is allocated to woody tissue and the rate of nutrient return decreases (Brown and Lugo, 1990).

A remarkably liner relation existed between species diversity and litter production and net primary productivity during the first to 20 years of succession in swidden fallow secondary forests in India. With the rapid transfer of nutrients from the soil to the vegetation during the early phase of fallow, rapid depletion of nutrients occurs in soil even though losses by leaching and runoff are greatly reduced. It is only after about 10 years of fallow that transfer of nutrients back to the soil through litterfall becomes important and soil fertility recovers (Ramakrishnan and Kushwaha, 2001)

McDonald and Healey (2000) found in studying primary and secondary forests in Jamaica that rates of nutrient loss in runoff and eroded sediment in secondary forest were low. Basal area had recovered to $81 \%$ of primary forest levels and rates of litterfall were high. Soil fertility had recovered well in the secondary forests. In the middle of steep slopes, following the cessation of agriculture, tight nutrient cycling and soil condition and fertility are effectively restored during ca. 20 years of secondary succession.

Johnson et al. (2001) compared nutrient concentrations and stocks in aboveground vegetation and soils between secondary forests (10-, 20-, and 40-yearold stands subject to repeated cycles of slash-and- burn agriculture) and a primary forest fragment in the Bragantina region of Brazil. There were no significant differences in median foliar tissue concentrations of $\mathrm{N}$, $\mathrm{P}, \mathrm{K}, \mathrm{Ca}$ or $\mathrm{Mg}$ between the secondary forests and the primary forest. In woody tissue, the primary forest had a lower median $\mathrm{Mg}$ concentration than all secondary forest plots and a higher median $\mathrm{N}$ concentration than the 40-year-old secondary forest. Foliar nutrient stocks were higher in the secondary forests than in the primary forest due to higher foliar biomass estimates for those plots. Aboveground woody nutrient stocks were the greatest in the primary forest with the exception of $\mathrm{Mg}$. Soil concentrations of exchangeable Ca decreased with increasing stand age; soil concentrations of exchangeable $\mathrm{Mg}$ were higher in all secondary plot soils than in the primary plot soil. Labile P stocks were greater in the primary forest soil than in all secondary forest soils.

Lugo (1992) reported that understory plant tissue, particularly leaf litter, had higher nutrient concentration in pine plantations than in paired secondary forests. Secondary forests recycled nutrients much faster than the plantations, which tended to store the nutrients. Litter of the secondary forests had a faster nutrient turnover than plantation litter.

Montagnini et al. (1995) studied the soil conditions of a 25-year secondary forest and a primary forest in Brazil. Their results show that soil pH, C, H, P, Ca and Mg were higher under secondary forest than under primary forest. Litter accumulation on the forest-floor was greater in secondary than in primary forest. Soil condition in the secondary forest may have improved as a result of the impacts of the dominant plant species in the regrowth.

Nutrients in litterfall released by litter decomposition. Variation in land management practices changes most of the factors that influence decomposition. Clearing and burning the vegetation for agricultural practices increases air and soil temperature and decreases soil moisture, which may lead to less litter input and a tendency toward slower decomposition of leaf litter than in the plots with canopy cover (Mesquita et al. 1998). Decomposition was related to forest development phase as well as leaf chemical composition. The earlier successional phase showed higher decomposition rates than later stages of succession, which was correlated with higher $\mathrm{P}$ concentration. Enhanced nutrient content favors more rapid decomposition in young forests, and enhanced microbial environments favor more rapid decomposition in older forests (Xuluc-Tolosa, 2003). 


\section{SOIL OF TROPICAL SECONDARY FORESTS}

Soil properties can affect the growth and species composition of colonists on deforested land. After deforestation or burning, soil structure becomes badly because of increase in bulk density and decrease in soil porosity. The loss of soil organic matter decreases the water-holding capacity of soils and soil fertility. During land clearing, $\mathrm{N}$ is lost mainly through biomass removal, volatilization during burning, denitrification, and leaching. The clearance of the secondary forest lead to large changes in most measured soil properties. Over 5 years amounts of organic matter declined by $298.00 \mathrm{~kg} \mathrm{ha}^{-1} \mathrm{a}^{-1}$, total $\mathrm{N}$ by $7.95 \mathrm{~kg} \mathrm{ha}^{-1} \mathrm{a}^{-1}$, exchangeable $\mathrm{K}$ by $0.45 \mathrm{~kg} \mathrm{ha}^{-1}$ $\mathrm{a}^{-1}$, exchangeable Ca by $7.11 \mathrm{~kg} \mathrm{ha}^{-1} \mathrm{a}^{-1}$ and exchangeable $\mathrm{Mg}$ by $0.57 \mathrm{~kg} \mathrm{ha}{ }^{-1} \mathrm{a}^{-1}$; over the same period bulk density increased by $0.4 \mathrm{Mg} \mathrm{m}^{-3}$. Of the soil properties more subject to year-to-year fluctuations, after 5 years the concentration of available P was 36\% (0.004 $\left.\mathrm{g} \mathrm{kg}^{-1}\right)$ less in cleared plots than in forest (McDonald et al. 2002). The recovery of soil to its previous functions varies with forest type (Neill et al. 1997). For instance, secondary forests that were formerly pastures have a faster recovery of soil carbon than former agricultural fields (Silver et al. 1996). Former agricultural fields subjected to fertilization may have greater amounts of nutrients than secondary forests that regrow after other land uses (Brown and Lugo, 1990). Despite these variations, once plants begin to colonize a site through the processes described before, a variety of soil-plant feedback processes facilitate the recovery of soil functions.

\section{RESEARCH EXPECTATION}

Population increases, quick development in industry and construction of large-scale foundation facilities cause large-scale forest land perturbations including intensive logging, mining, conversion of forest lands to largescale plantations and agriculture, as well as construction of dams, roads and other infrastructure. The number and area of secondary forests tend to increase. Tropical secondary forests as an important form of tropical forests have received the international social extensive concern in recent years. Tropical secondary forests become an important research content.

Regeneration from seed has been studied by some researchers, whereas study on re-sprouting from tree stumps and root-stocks is little, which is an important mechanism of regeneration for remaining primary forest species in highly fragmented landscapes. Much of emphasis in secondary succession has focused on dominating species or group of species during every stages of succession (Finegan, 1992). Differences in growth rates among species at different stages play an important role in succession. In order to accelerate succession, research of promoting tree growth by silvicultural treatments such as liberation thinning, refinement, and cleanings should be reinforced in the future study. Understanding how forests recover after logging is still a current research topic (Brown and Lugo, 1990; Lugo, 1992; Holl, 1999), the impact of logging on animal species and the impact of forest fragmentation on plant and animal species should not be neglected. The sample is insufficient to provide statistical descriptions linking rates of succession to logging and fire. Little is known about the effects of soil types, litter decomposition, prior land use on biomass accumulation. Fixed position study, the study on changes of microorganism, animal or other abiotic factors with forest succession is little. A multidisciplinary study including vegetation structures, key groups of plant, animal and microorganism species, plant functional types and abiotic factors, such as soil nutrient will establish useful linkages between these factors. Basic researches about successional mechanism, such as interspecific relationship, species niches and plant physiological and ecological characteristics during successional process are lacking. There has been little scientific integration of the structural and functional characteristics and processes that occur during secondary succession. These contents remain to make progress in future study of tropical secondary forests.

ACKNOWLEDGEMENT This study was supported by ITTO Project[ITTO PPD 30/01 Rev.1 (F)]

\section{REFERENCES}

Aiba, S., Hill, D.A. \& Agetsuma, N. 2001. Comparison between old-growth stands and secondary stands regenerating after clear-felling in warm-temperate forests of Yakushima, southern Japan. Forest Ecology and Management, 140: 163-175.

Aide, T.M. \& Cavelier, J. 1994. Barriers to lowland tropical forest restoration in the Sierra Nevada de Santa Marta, Colombia. Restoration Ecology, 2: 219-229.

Aide, T.M., Zimmerman, J.K., Rosario, M. \& Marcano, H. 1996. Forest recovery in abandoned cattle pastures along an elevational gradient in Northeastern 
Puerto Rico. Biotropica, 28: 537-548.

Bartholomen, W.V., Meyer, J. \& Laudelot, H. 1953. Mineral nutrient immobilization under forest and grass fallow in the Yangambi (Belgian Congo) region. Publications de L'Institut National pour L'Etude Agronomique du Congo Belge, Série Scientifique No: 57, 27pp.

Basnet, K., Likens, G.E., Scatena, F.N. \& Lugo, A.E. 1992. Hurricane Hugo: damage to a tropical rain forest in Puerto Rico. Journal of Tropical Ecology, 8: 47-55.

Bebber, D., Brown, N., Speight, M., Moura-Costa, P. \& Wai, Y.S. 2002. Spatial structure of light and dipterocarp seedling growth in a tropical secondary forest. Forest Ecology and Management, 157: 65-75.

Brearley, F.Q., Prajadinata, S., Kidd, P.S., Proctor, J. \& Suriantat. 2004. Structure and floristics of an old secondary rain forest in Central Kalimantan, Indonesia, and a comparison with adjacent primary forest. Forest Ecology and Management, 195: 385-397.

Brown, S. \& Lugo, A.E. 1990. Tropical secondary forests. Journal of Tropical Ecology, 6: 1-32.

Cain, M.D. \& Shelton, M.G. 2001. Secondary forest succession following reproduction cutting on the Upper Coastal Plain of southeastern Arkansas, USA. Forest Ecology and Management, 146: 223-238.

Cannon, C.H, Peart, D.R. \& Leighton, M. 1998. Tree species diversity in commercially logged Bornean rainforest. Science, 281: 1366-1368.

Cavelier, J., Estevez, J. \& Arjona, B. 1996. Fine root biomass in three successional stages of an Andean cloud forest in Colombia. Biotropica, 28: 728-736.

Chapin, F.S., Vitousek, P.M. \& Van Cleeve, K. 1986. The nature of nutrient limitation in plant communities. American Naturalist, 127: 48-58.

Chazdon, R.L. \& Coe, F.G. 1999. Ethnobotany of woody species in second growth, and selectively logged forests of Northeastern Costa Rica. Conservation Biology, 13: 1312-1322.

Chinea, J.D. \& Helmer, E.H. 2003. Diversity and composition of tropical secondary forests recovering from large-scale clearing: results from the 1990 inventory in Puerto Rico. Forest Ecology and Management, 180: 227-240.

Chokkalingam, U., Smith, J. \& de Jong, W. 2001. A conceptual framework for the assessment of tropical secondary forests dynamics and sustainable development potential in Asia. Journal of Tropical Forest Science, 13: 577-600.

Dennis, R., Hoffmann, A., Applegate, G., von
Gemmingen, G. \& Kartawinata, K. 2001. Large-scale fire: creator and destroyer of secondary forests in Western Indonesia. Journal of Tropical Forest Science, 13: 786-799.

Denslow, J.S. \& Guzman, S. 2000. Variation in stand structure, light, and seeding abundance across a tropical moist forest chronosequence, Panama. Journal of Vegetation Science, 11: 201-212.

Díaz, M., Carbonell, R., Santos, T. \& Tellería, J.L. 1998. Breeding bird communities in pine plantations of the Spanish plateaux: biogeography, landscape and vegetation effects. Journal of Applied Ecology, 35: 562-574.

Dotzauer, H. 1998. The potential of secondary forest management from a development policy point of view: An overview. In: Plant Research and Development 47/48 (eds. Bittner, A., Achtnich, W., Atanasiu, N., Böger, P., Caesar, K., Hoeppe, C. \& Guo, L.), pp. 79-87. Tübginen: Institute for scientific Co-operation.

Dupuy, J.M. \& Chazdon, R.L. 1998. Long-term effects of forest regrowth and selective logging on the seed bank of tropical forests in NE Costa Rica. Biotropica, 30: 223-237.

Echeverría, C. \& Lara, A. 2004. Growth patterns of secondary Nothofagus obliqua-N. alpina forests in southern Chile. Forest Ecology and Management, 195: 29-43.

FAO. Forest resources assessment 1990. 1996. Survey of tropical forest cover and study of change processes. FAO Forestry Paper 13. Rome.

Fearnside, P.M. \& Guimaraes, W.M. 1996. Carbon uptake by secondary forests in Brazilian Amazonia. Forest Ecology and Management, 80: 35-46.

Finegan, B. 1992. The management potential of neotropical secondary lowland rain forest. Forest Ecology and Management, 47: 295-321.

Finegan, B. 1996. Pattern and process in neotropical secondary rain forest: the first 100 years of succession. Trends in Ecology Evolution, 11: 119-124.

Fu, S., Pedraza, C.R. \& Lugo, A.E. 1996. A twelveyear comparison of stand changes in a Mahogany plantation and a paired natural forest of similar age. Biotropica, 28: 515-524.

Garcia, S., Finch, D.M. \& León, G.C. 1998. Patterns of forest use and endemism in resident bird communities of north-central Michoacán, Mexico. Forest Ecology and Management, 110: 151-171.

Garwood, N.C. 1989. Tropical soil seed banks: a 
review. In: Ecology of Soil Seed Banks, (eds. Leck, M.A., Parker, V.T. \& Simpson, R.L.), pp. 149-209. Academic Press, San Diego.

Gjerde, I. \& Sætersdal, M. 1997. Effects on avian diversity of introducing spruce Picea spp. plantations in the native pine Pinus sylvestris forests of western Norway. Biological Conservation, 79: 241-250.

Greig-Smith, P. 1952. Ecological observations on degraded and secondary forest in Trinidad, British West Indies. I. General features on the vegetation. Journal of Ecology, 40: 283-315.

Guan, D-S. 1996. Primary productivity and nutrients in the plant communities of succession in southern subtropical zone of South China. Chinese Journal of Ecology, 15: 11-14.

Guariguata, M.R., Chazdon, R.L., Denslow, J.S., Dupuy, J.M. \& Anderson, L. 1997. Structure and floristics od secondary and old-growth forest stands in lowland Costa Rico. Plant Ecology, 132: 107-120.

Harcombe, P.A. 1977. The influence of fertilization on some aspects of succession in a humid tropical forest. Ecology, 58: 1375-1383.

Herrera, B. \& Finegan, B. 1997. Substrate conditions, foliar nutrients and the distributions of two canopy tree species in a Costa Rican secondary rain forest. Plant and Soil, 191: 259-267.

Holl, K.D. 1999. Factors limiting tropical rain forest regeneration in abandoned pasture: seed rain, seed germination, microclimate, and soil. Biotropica, 31: 229-242.

Holl, K.D. \& Lulow, M.E. 1997. Effects of species, habitat, and distance from edge on post-dispersal seed predation in a tropical rain forest. Biotropica, 29: 459-468.

ITTO. 1989. Pre-Project Study Report: Enrichment Planting. International Timber Trade Organization.

ITTO. 2002. Guidelines for the restoration, management and rehabilitation of degraded and secondary tropical forests. Thirty-second Session Bali, Indonesia.

Johnson, C.M., Vieira, I.C.G., Zarin, D.J., Frizano, J. \& Johnson, A.H. 2001. Carbon and nutrient storage in primary and secondary forests in eastern Amazonia. Forest Ecology and Management, 147: 245-252.

Johnson, C.M., Zarin, D.J. \& Johnson, A.H. 2000. Postdisturbance aboveground biomass accumulation in global secondary forests: climate, soil texture, and forest type effects. Ecology, 81: 1395-1401.

Kartawinata, K., Riswan, S., Gintings, A.N. \& Puspitojati, T. 2001. An overview of post-extraction secondary forests in Indonesia. Journal of Tropical Forest Science, 13: 621-638.

Kellman, M.C. 1970. Secondary plant succession in tropical montane Mindanao. Australian National University Publication BG/2. Canberra: Australian National University.

Kwok, H.K. \& Corlett, R.T. 2000. The bird communities of a natural secondary forest and a Lophostemon confertus plantation in Hong Kong, South China. Forest Ecology and Management, 130: 227-234.

Laska, M.S. 1997. Structure of understory shrub assemblages in adjacent secondary and old growth tropical wet forests, Costa Rica. Biotropica, 29: 29-37.

Leak, W.B. 1991. Secondary forest succession in New Hampshire, USA. Forest Ecology and Management, 43: 69-86.

Lu, D-S, Mausel, P., Brondízio, E. \& Moran, E. 2003. Classification of successional forest stages in the Brazilian Amazon basin. Forest Ecology and Management, 181: 301-312.

Lugo, A.E. 1992. Comparison of tropical tree plantation with secondary forests of similar age. Ecological Monograph, 62: 1-41.

Lugo, A.E. \& Brown, S. 1992. Tropical forests as sinks of atmospheric carbon. Forest Ecology and Management, 54: 239-255.

McDonald, M.A. \& Healey, J.R. 2000. Nutrient cycling in secondary forests in the Blue Mountains of Jamaica. Forest Ecology and Management, 139: 257-278.

McDonald, M.A., Healey, J.R. \& Stevens, P.A. 2002. The effects of secondary forest clearance and subsequent land-use on erosion losses and soil properties in the Blue Mountains of Jamaica. Agriculture, Ecosystems and Environment, 92: 1-19.

Mesquita, De C.G.R., Workman, S.W. \& Neely, C.L. 1998. Slow litter decomposition in a Cecropia-dominated secondary forest of central Amazonia. Soil Biology \& Biochemistry, 30: 167-175.

Montagnini, F., Fanzeres, A. \& Vinha, S.G.D. 1995. The potentials of 20 indigenous tree species for soil rehabilitation in the Atlantic forest region of Bahia, Brazil. Journal of Application Ecology, 32: 841-856.

Neill, C., Melillo, J.M., Steudler, P.A., Cerri, C.C., de Moraes, J.F.L, Piccolo, M.C. \& Brito, M. 1997. Soil carbon and nitrogen stocks following forest clearing for pasture in the southwestern Brazilian Amazon. Ecological Application, 70: 1216-1225.

Nepstad, D.C., de Carvalho, C.R., Davidson, E.A., Jipp, P.H., Lafabvre, P.A., Negreiros, G.H., da Silva, E.D., 
Stone, T.A., Trumbore, S.E. \& Vieira, S. 1994. The role of deep roots in the hydrological and carbon cycles of Amazonian forests and pastures. Nature, 372: 666-669.

Nepstad, D.C., Uhl, C., Pereira, C.A. \& da Silva, J.M.C. 1996. A comparative study of tree establishment in abandoned pasture and mature forest of eastern Amazonia. Oikos, 76: 25-39.

Oberhauser, U. 1997. Secondary forest regeneration beneath pine (Pinus kesiya) plantations in the northern Thai highlands: a chronosequence study. Forest Ecology and Management, 99: 171-183.

Olander, L.P., Scatena, F.N. \& Silver, W.L. 1998. Impacts of disturbance initiated by road construction in a subtropical cloud forest in the Luquillo Experimental Forest, Puerto Rico. Forest Ecology and Management, 109: 33-49.

Otsamo, R. 2000. Secondary forest regeneration under fast-growing forest plantations on degraded Imperata cylindrica grasslands. New Forests, 19: 69-93.

Parrotta, J.A. 1993. Secondary forest regeneration on degraded tropical lands: The role of plantations as ' foster ecosystems' In: Restoration of Tropical Ecosystems, (eds. Lieth, H. \& Lohmann, M.), pp. 63-73. Kluwer, Dordrecht.

Parrotta, J.A., Turnbull, J.W. \& Jones, N. 1997. Catalyzing native forest regeneration on degraded tropical lands. Forest Ecology and Management, 99: 1-7.

Pascarella, J.B., Aide, T.M. \& Zimmerman, J.K. 2004. Short-term response of secondary forests to hurricane disturbance in Puerto Rico, USA. Forest Ecology and Management, 199: 379-393.

Perera, G.A.D. 2001. The secondary forest situation in Sri Lanka: a review. Journal of Tropical Forest Science, 13: $768-785$.

Putz, F.E. 1983. Treefall pits and mounds, buried seeds, and the importance of soil disturbance to pioneer trees on Barro Colorado Island, Panama. Ecology, 64: 1069-1074.

Raich, J.W. \& Gong, W.K. 1990. Effects of canopy openings on tree seed germination in a Malaysian dipterocarp forest. Journal of Tropical Ecology, 6: 203-217.

Ramakrishnan, P.S. \& Kushwaha, S.P.S. 2001. Secondary forests of the Himalaya with emphasis on the northeastern hill region of India. Journal of Tropical Forest Science, 13: 727-747.

Rivera, L.W. \& Aide, T.M. 1998. Forest recovery in the karst region of Puerto Rico. Forest Ecology and
Management, 108: 63-75.

Ross, R. 1954. Ecological studies on the rain forest of Southern Nigeria. III. Secondary succession in the Shasha reserve. Journal of Ecology, 42: 259-282.

Saldarriaga, J.D., West, D.C., Tharp, M.L. \& Uhl, C. 1988. Long-term chronosequence of forest succession in the upper Rio Negro of Colombia and Venezuela. Journal of Ecology, 76: 938-958.

Silver, W.L., Scatena, F.N., Johnson, A.H., Siccama, T.G. \& Watt, F. 1996. At what temporal scales does disturbance affect belowground nutrient pools? Biotropica, 28: 441-457.

Thomlinson, J.R., Serrano, M.I., del M López, T., Aide, T.M. \& Zimmerman, J.K. 1996. Land-use dynamics in a post-agriculture Puerto Rican landscape (1936-1988). Biotropica, 28: 525-536.

Ticktin, T. \& Nantel, P. 2004. Dynamics of harvested populations of the tropical understory herb Aechmea magdalenae in old-growth versus secondary forests. Biological Conservation, 120: 461-470.

Toky, O.P. \& Ramakrishnan, P.S. 1983. Secondary succession following slash-and-burn agriculture in north-eastern India. I. Biomass, litterfall and productivity. Journal of Ecology, 71: 735-745.

Uhl, C. 1987. Factors controlling succession following slash-and burn agriculture in Amazonia. Journal of Ecology, 75: 377-407.

Uhl, C., Clark, K., Clark, H. \& Murphy, P. 1981. Early plant succession after cutting and burning in the upper Rio Negro region of the Amazon basin. Journal of Ecology, 69: 631-649.

Uh1, C., Buschbacher, R. \& Serrao, E.A.S. 1988. Abandoned pastures in eastern Amazonia. I. Patterns of plant succession. Journal of Ecology, 76: 663-681.

Walker, L.R. 1991. Tree damage and recovery from Hurricane Hugo in the Luquillo Experimental Forest. Puerto Rico. Biotropica, 23: 379-385.

Xiao, Z-S., Zhang, Z-B., Wang, Y-S. 2004. Dispersal and germination of big and small nuts of Quercus serrata in a subtropical broad-leaved evergreen forest. Forest Ecology and Management, 195: 141-150.

Xuluc-Tolosa, F.J., Vestera, H.F.M., Ramı́rez-Marcial, N., Castellanos-Albores, J. \& Lawrence, D. 2003. Leaf litter decomposition of tree species in three successional phases of tropical dry secondary forest in Campeche, Mexico. Forest Ecology and Management, 174: 401-402.

Young, K.R., Ewel, J.J. \& Brown, B.J. 1987. Seed dynamics during forest succession in Costa Rica. 
Vegetatio, 71: 157-173.

Zimmerman, J.K, Aide, T.M., Rosario, M., Serrano, M. \& Herrera, L. 1995. Effects of land management and a recent hurricane on forest structure and composition in the Luquillo Experimental Forest, Puerto Rico. Forest Ecology and Management, 77: 65-76.

Zimmerman, J.K. et al. 1996. Past land use as an important determinant of species composition in secondary forests of Puerto Rico. Paper presented at the Symposium "Ecological processes in low land tropical secondary forests", held at IITF, Puerto Rico.

Received $14^{\text {th }}$ Nov. 2005

Accepted $20^{\text {th }}$ Sep. 2006 